\title{
Effects of in situ experimental shading on the Mediterranean seagrass Posidonia oceanica
}

\author{
Juan Manuel Ruiz ${ }^{1, *}$, Javier Romero ${ }^{2}$ \\ ${ }^{1}$ Departamento de Ecología e Hidrología, Facultad de Biología, Universidad de Murcia, Campus Universitario de Espinardo, \\ 30100 Murcia, Murcia, Spain \\ ${ }^{2}$ Departament d'Ecologia, Universitat de Barcelona, Avda. Diagonal 645, 08028 Barcelona, Spain
}

\begin{abstract}
The response of the Mediterranean seagrass Posidonia oceanica (L.) Delile to in situ light reduction was examined over a 4 mo period (May to August) in 1993 and 1995. Shoot density, leaf growth rate, shoot size, photosynthetic activity, carbohydrate reserves, epiphyte load and tissue nutrient concentrations were measured in replicated plots under the following light conditions: ambient (36\% of surface irradiance [SI] control plots), moderately shaded plots (16.7\% SI, MS plots) and severely shaded plots (10.4\% SI, SS plots). By the end of the experimental period, all shoots under SS treatments had died, while 70 to $80 \%$ had survived under MS treatment; in control plots, shoot densities had remained almost constant. Leaf growth rate and biomass decrease with shading were evident $30 \mathrm{~d}$ after the beginning of the experiment; shoot density and number of leaves per shoot also fell with shading, but this was apparent only 60 to $90 \mathrm{~d}$ after the onset of the shading treatments. Epiphyte load was also considerably reduced by shading. Photosynthetic activity $\left(P_{\max }\right)$ and dark respiration rates $(R)$ of control plants showed a characteristic increase from spring (May) to the end of summer (August), resulting in higher saturation $\left(I_{\text {sat }}\right)$ and compensation $\left(I_{\mathrm{c}}\right)$ points and lower photosynthetic efficiencies $(\alpha)$ at the end of the experimental period; however, photosynthetic parameters in shaded plants (MS treatment) first increased (as in control plots) from May to June, but decreased afterwards (from June to August), indicating photoacclimation of $P$. oceanica to low light conditions. Shading depressed carbohydrate storage in the rhizomes of shaded plants, in which starch concentrations were quickly reduced to $60 \%$ of those of control plants. The leaves of shaded shoots showed a significant increase in nutrient (specially nitrogen) concentrations. This was probably due to translocation from shed leaves and also to low utilisation rates for growth. We infer that minimum light requirements of $P$. oceanica are between 16 and $10 \%$, of surface irradiance, values which are consistent with light availability at the deep limits of nearby meadows. One year after shades had been removed, shoot densities remained unchanged (relative to the moment of screen removal), indicating both the absence of cascading effects and a very low recovery capacity of this seagrass.
\end{abstract}

KEY WORDS: Shading $\cdot$ Seagrass decline $\cdot$ Photosynthesis $\cdot$ Carbohydrates

\section{INTRODUCTION}

Light is considered one of the main environmental factors that regulates the abundance and distribution of seagrasses, and, in the absence of other limiting fac-

\footnotetext{
*Present address: Instituto Español de Oceanografía, Centro Oceanográfico de Murcia, 30740 Lo Pagán, San Pedro del Pinatar, Murcia, Spain. E-mail: jmruiz@mu.ieo.es
}

tors (e.g. those relative to substrate characteristics), it plays a key role in determining a number of seagrass features, such as the depth limit distribution (Duarte 1991, Zimmerman et al. 1991), spatial structure (Dennison 1987, Lee \& Dunton 1997) and seasonal growth pattern (Dennison 1987, Alcoverro et al. 1995). The effects of light attenuation on seagrasses has been examined using several strategies or approaches: correlational (i.e. quantitative analysis along depth gradi- 
ents: Dennison \& Alberte 1985, Dawes \& Tomasko 1988, West 1990), ecophysiological (study of photosynthetic performances and estimation of carbon budgets: Dennison 1987, Zimmerman et al. 1991, Alcoverro 1995, Terrados \& Ros 1995) and experimental (in situ light manipulations using screens: Backman \& Barilotti 1976, Dennison \& Alberte 1982, Bulthuis 1983, Neverauskas 1988, Gordon et al. 1994, Czerny \& Dunton 1995, Fitzpatrick \& Kirkman 1995, Lee \& Dunton 1997). The results obtained so far indicate that seagrass abundance, growth and distribution are extremely sensitive to changes in light availability.

There is increasing concern about the consequences of human impact on seagrass ecosystems in coastal zones (Pérès 1984, Shepherd et al. 1989, Walker \& McComb 1992). Light reduction caused by increased turbidity or in combination with other side effects of human activity, particularly eutrophication (e.g. increased epiphyte loading), has been identified as one of the main causes of seagrass decline (Larkum \& West 1983, Silverstein et al. 1986, Neverauskas 1987, Giesen et al. 1990, Pullich \& White 1991, Zimmerman et al. 1991, 1995, Moore et al. 1997). This decline, which appears to be world-wide, is especially dramatic in densely populated areas. This is the case for the Mediterranean, and especially its NW part, where the rapid decline of the dominant endemic Posidonia oceanica (L.) Delile has traditionally been attributed to a wide variety of human impacts, such as coastal constructions (Meinesz et al. 1982, Blanc \& Jeudy de Grissac 1989, Ruiz et al. 1993), industrial and urban sludge outfalls (Bourcier 1989, Pergent-Martini \& Pergent 1995), fish farm residuals (Delgado et al. 1997, 1999) and trawl fishing (Sánchez-Lizaso et al. 1990). Light attenuation, nutrient and/or organic loads and sediment level changes have also been proposed as proxy causes for seagrass decline (e.g. Marbà \& Duarte 1997, Manzanera et al. 1998).

It is reasonable to assume that among seagrass species, those having the highest belowground biomass are the most sensitive to light reduction (Dennison 1987, Lee \& Dunton 1997). Thus, for Posidonia oceanica, a high sensitivity to changes in water transparency is expected, probably due to the heavy burden imposed by the respiratory demand of its massive belowground biomass (Alcoverro 1995). However, massive underground organs also allow large carbon stores (as soluble carbohydrates) to sustain growth and respiration during the unfavourable conditions of winter (Pirc 1986, Alcoverro et al. 2001). As shown for other species (P. sinuosa, Masini et al. 1995; Thalassia testudinum, Lee \& Dunton 1997), the interplay between light reduction and reserves storage can be crucial in understanding the seagrass response (in terms of mortality) to increased water turbidity, and it has been suggested that the decrease in rhizome carbon reserves could be a reliable indicator of seagrass decline (Lee \& Dunton 1997). However, this contention has never been experimentally tested, and the timecourse of seagrass decline following light reduction (mortality, changes in morphological features, etc.) is only poorly understood.

In this study we examine the in situ response of the seagrass Posidonia oceanica to experimental light attenuation under field conditions during its growing season, and we evaluate the potential of this factor to cause seagrass mortality, both immediate (i.e. during the period of light reduction) and delayed, potentially due to carbon reserve depletion. To do so, we manipulated the light availability of an undisturbed P. oceanica meadow using shading screens, and the subsequent changes in a series of descriptors of plant vitality and meadow structure were measured. Shading was applied during spring-summer, which is the time of the year when the carbon balance is the most positive and when this species stores carbohydrate reserves that will be used for overwintering. To assess the long-term effect of shading, plant survival was monitored for $1 \mathrm{yr}$ after the onset of experimental shading.

\section{METHODS}

Experiments were conducted in an apparently healthy, dense (i.e. 500 to 600 shoots $\mathrm{m}^{-2}$ ) Posidonia oceanica meadow (8 to $10 \mathrm{~m}$ deep) at Fraile Island, Aguilas (Murcia, Spain; Fig. 1), far from any known potential human impact. The site is partially protected against physical disturbances caused by prevailing winds (strong NE and SW storms). Variations in water temperature and underwater irradiance showed a characteristic seasonal pattern for Mediterranean coastal areas (Fig. 2).

Two shading levels (40 and $70 \%$ ) were applied to obtain nominally 60 and $30 \%$ of incident light at the top of the canopy, relative to an equivalent, unshaded area. These are called hereafter moderate shading (MS) and severe shading (SS). A total of 6 MS and 6 SS screens were randomly placed in the meadow under study, separated 5 to $10 \mathrm{~m}$ from each other.

Screens $\left(4 \mathrm{~m}^{2}\right)$ were made of common plastic shadecloth, with different net densities to obtain the desired shading levels. Shadecloth sheets were supported by a PVC frame which maintained the screens $0.5 \mathrm{~m}$ above the leaf canopy; screens were attached with ropes to steel bars anchored in the rhizome-sediment layer to minimize interference with water movements. Only 2 losses (immediately repaired) occurred over the experimental period. To prevent fouling and subsequent overshading, screens were cleaned every 2 to $3 \mathrm{~d}$. 


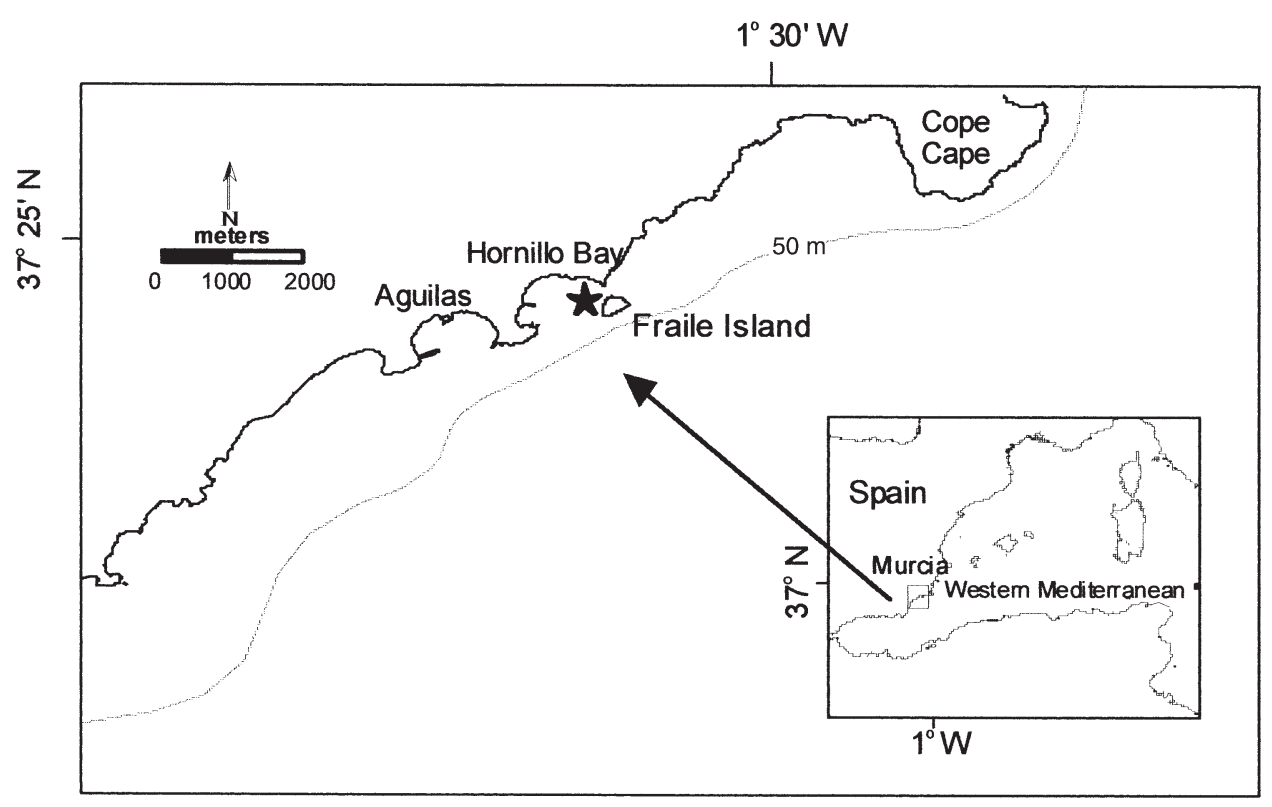

Fig. 1. Study area at Fraile Island, Aguilas (Murcia, Spain). ( $\star$ Experimental site

To assess light conditions, in situ light measurements (400 to $700 \mathrm{~nm}$, photosynthetic photon flux density, PPFD, $\mu$ mol quanta $\mathrm{m}^{-2} \mathrm{~s}^{-1}$ ) were performed using a $2 \pi$, cosine-corrected underwater PAR sensor (Li-Cor LI192SA). To characterise the effect of experimental manipulations on ambient light conditions, variations in daily-integrated PPFD ( $\mathrm{mol}$ quanta $\mathrm{m}^{-2} \mathrm{~d}^{-1}$ ), the coefficient of light attenuation $\left(k, \mathrm{~m}^{-1}\right)$ and the percentage of surface irradiance (\% SI) above the meadow leaf canopy were estimated for each experimental condition in May, June and July. The dailyintegrated PPFD above the meadow leaf canopy was estimated by integration of light curves obtained on clear sunny days $\left(2 \mathrm{~d} \mathrm{mo}^{-1}\right)$; these curves were constructed by measuring PPFD (mean of continuous measures recorded every second for $5 \mathrm{~min}$ ) at $1 \mathrm{~h}$ intervals, from dawn to dusk. $k$ and the percentage of surface light reaching the canopy were estimated from simultaneous measurements of instantaneous PPFD at the sea surface $\left(I_{\mathrm{s}}\right)$ and just above the meadow leaf canopy $\left(I_{z}\right)$; the measurements were performed at noon (12:00 to $14: 00 \mathrm{~h}$ ) to minimise apparent effects of solar zenith angle (Moore et al. 1997); $k$ was calculated from the Beer-Lambert expression $\left(I_{z}=I_{\mathrm{s}} \cdot \mathrm{e}^{-k z}\right)$, where $z$ represents depth at the experimental site (a mean of $9 \mathrm{~m}$ ). Simultaneous measurements of $I_{\mathrm{s}}$ and $I_{\mathrm{z}}$ were obtained on 10 days randomly distributed over the experimental period.

Screens were emplaced in May and removed in August, a period which encompasses maximum growth and photosynthetic rates, and maximum carbon storage in rhizomes for Posidonia oceanica (Pirc 1986, Alcoverro et al. 1995). The first experiment was conducted in 1993 and partially reproduced (only with MS screens) in 1995. The 1995 experiment included the monitoring of shoot density 9 mo after screen removal.

Several plant descriptors were measured in shaded plots and in 3 randomly chosen control plots interspersed among the shaded ones. Shoot density was estimated monthly as the total number of living shoots within $0.0625 \mathrm{~m}^{2}$ fixed quadrats placed in shaded and control plots. Leaf growth was estimated using a marking technique (Zieman 1974, Romero 1989, Alcoverro et al. 1995). Two holes were punched in all the leaves of the shoot, just above the ligula of the outermost, old-

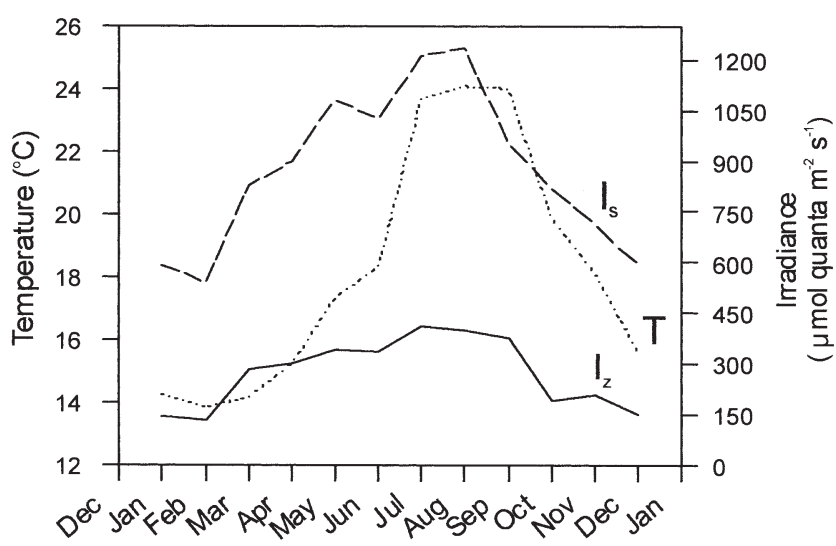

Fig. 2. Annual variations in water sub-surface $(-3 \mathrm{~m})$ temperature $\left(T\right.$, dotted line), surface irradiance $\left(I_{\mathrm{s}}\right.$, dashed line) and irradiance at the leaf canopy level $\left(I_{z}\right.$, solid line) at the experimental site (control plots) 
est leaf, with a hypodermic needle. At each sampling visit, 10 shoots were marked in each of 3 plots randomly selected from the 6 of each experimental condition and in the 3 control plots. The time between successive sampling events varied from 20 to $30 \mathrm{~d}$, with a total of 3 sampling events in 1993 and 5 in 1995. Initial shoot densities of experimental plots were 300 to 400 shoots $\mathrm{m}^{-2}$; consequently, shoot removal due to sampling was (at the end of the experiments) always below $5 \%$ of initial shoot number. We consider thus that the sampling effect on the subpopulations was negligible. In the laboratory, leaves were separated from rhizomes and leaf elongation was measured as the displacement of holes relative to the ligula of the outermost leaf. For each shoot, leaf length and width were measured and the shoot leaf surface was calculated $\left(\mathrm{cm}^{2}\right.$ shoot $\left.^{-1}\right)$. Epiphytes were removed from the harvested shoots using a razor blade, which has been shown to remove most of the macroscopic and microscopic epiphytes (Kirchman et al. 1984), and 'new' (i.e. that present in the moment of collection between the reference level of the marks and the actual position of the holes) and 'old' (the rest) tissue were separated, dried $\left(70^{\circ} \mathrm{C}\right.$ for $12 \mathrm{~h}$ ) and weighed. Epiphytes were also dried and weighed and epiphyte load in a shoot was determined as the epiphyte biomass per leaf surface unit (mg dw [dry weight] $\mathrm{cm}^{-2}$ ). Shoot size was estimated as total shoot leaf biomass ( $\mathrm{g} \mathrm{dw}$ shoot $^{-1}$ ). Leaf growth rate (mg $\mathrm{dw}$ shoot $^{-1} \mathrm{~d}^{-1}$ ) was determined by dividing the weight of new tissue by the period (days) elapsed between successive sampling events.

Photosynthesis-irradiance $(P-I)$ curves were obtained between 0 and $800 \mu \mathrm{mol}$ quanta $\mathrm{m}^{-2} \mathrm{~s}^{-1}$ for shaded and control plants in July 1993 (i.e. after 2 mo of shading) and in June, July and August 1995 (after 20, 50 and $90 \mathrm{~d}$ of shading, respectively). For $P$ - $I$ incubations, 30 plants were randomly collected in the morning (08:00 to 09:00 h) from the different shaded and control plots and transported in aerated and refrigerated seawater to the laboratory within $2 \mathrm{~h}$ of collection. For incubations, 10 to $15 \mathrm{~cm}$ leaf segments were separated from the second youngest leaf of each shoot, where photosynthetic activity is highest in Posidonia oceanica (Alcoverro et al. 1998). Epiphyte cover is very low in this age class of tissue; however, whenever necessary, leaf segments were gently cleaned of epiphytes using a razor blade. Rhizomes were kept frozen for carbohydrate and nutrient analysis (see below).

Three leaf segments obtained from 3 different shoots were incubated for each irradiance level. Each leaf segment was placed in 250 to $300 \mathrm{ml}$ glass bottles filled with seawater and placed in an incubator where temperature was kept constant at the value recorded at the time of collection. Light was provided by halogen lamps, and the different irradiances $(0,25,50,150,250$,
500 and $800 \mu \mathrm{mol}$ quanta $\mathrm{m}^{-2} \mathrm{~s}^{-1}$ ) were obtained by inserting natural density filters. Bottle stirring was carried out using multisite magnetic stirrers (ca $200 \mathrm{rpm}$ ). After $2 \mathrm{~h}$ of incubation, the dissolved oxygen concentration inside the glass bottles was measured using an oxygen probe (Orbisphere, 27141), and values obtained in 4 control bottles (without plants; coefficient of variation among final oxygen concentration in control bottles: 0 to $1.2 \%$ ) were subtracted. After incubation, plant material was dried at $100^{\circ} \mathrm{C}$ for $24 \mathrm{~h}$ and subsequently weighed. Net photosynthesis (or respiration) was expressed as the net oxygen release (or uptake) per unit weight and unit time $\left(\mathrm{mg} \mathrm{O}_{2} \mathrm{~g}^{-1} \mathrm{dw} \mathrm{h} \mathrm{h}^{-1}\right)$. This method has proved to give reliable estimates of photosynthetic activity (Alcoverro et al.1998).

$P$ - $I$ curve results were fitted to the equation of Edwards \& Walkers (1983) modified by Pérez \& Romero (1992) to estimate photosynthetic parameters:

$$
P=P_{\max } \cdot\left(I-I_{\mathrm{c}}\right) /\left[I_{\mathrm{sat}}+\left(I-I_{\mathrm{c}}\right)\right]
$$

where $P$ is the net oxygen release $\left(\mathrm{mg} \mathrm{O}_{2} \mathrm{~g}^{-1} \mathrm{dw} \mathrm{h} \mathrm{h}^{-1}\right.$ ), $I$ the irradiance ( $\mu \mathrm{mol}$ quanta $\mathrm{m}^{-2} \mathrm{~s}^{-1}$ ), $P_{\max }$ the net oxygen release at saturating irradiance $\left(\mathrm{mg} \mathrm{O}_{2} \mathrm{~g}^{-1} \mathrm{dw} \mathrm{h}^{-1}\right)$, $I_{\mathrm{c}}$ the compensating irradiance ( $\mu \mathrm{mol}$ quanta $\mathrm{m}^{-2} \mathrm{~s}^{-1}$ ) and $I_{\text {sat }}$ the saturating irradiance ( $\mu \mathrm{mol}$ quanta $\mathrm{m}^{-2} \mathrm{~s}^{-1}$ ), as classically defined by most authors (e.g. Drew 1983, Lüning 1990). Experimental data were fitted to the above equation using the SIGMA PLOT non-linear curve fitter (Jandel Scientific $^{\odot}$ 1992). In the 1995 experiment, 2 independent $P-I$ curves (using 2 independent subsets of shoots) were obtained, allowing thus 2 independent estimates (replicates) of each photosynthetic parameter. This was not the case for the 1993 experiment, in which only $1 P-I$ curve was obtained for each experimental condition.

For comparative purposes, rough estimates of leaf carbon balance in shaded and control plants were obtained from daily light curves and photosynthetic parameters $\left(I_{\text {sat }}, P_{\text {max }}\right)$ corresponding to each month in the experimental period. We first estimated $H_{\text {sat, }}$ i.e. the number of daily hours in which the plants receive a PPFD that exceeds $I_{\text {sat }}$ (Dennison 1987). The net daily photosynthetic production of leaves was calculated by multiplying $H_{\text {sat }}$ by the mean $P_{\max }$ corresponding to each experimental treatment and period. Oxygen production estimates were converted to carbon units (i.e. daily $\mathrm{C}$ net gain of leaves) by multiplying by 0.3 , assuming a photosynthetic quotient of 1.25 , which has been considered representative for seagrasses (Westlake 1963, McRoy \& McMillan 1977, Dennison 1987).

In the 1995 experiments, starch and soluble carbohydrates in rhizomes were determined 20, 50 and $90 \mathrm{~d}$ after the beginning of the shading treatment. In order to assess the possibility of carbon reserves depletion in shaded plants during the unfavourable growth season, 
at the end of the shading period starch was also measured at 2 additional times corresponding to 30 and $75 \mathrm{~d}$ after screen removal. Carbohydrate analysis was performed in ground, dried $\left(100^{\circ} \mathrm{C}\right.$ for $\left.24 \mathrm{~h}\right)$ rhizome fragments (4 to $6 \mathrm{~cm}$ from rhizome apex) obtained from 5 shoots in each sample taken for leaf growth and biomass estimates ( 3 independent samples per treatment and sampling event; see above). Soluble carbohydrates were extracted from the sample in hot $\left(80^{\circ} \mathrm{C}\right)$ ethanol and measured using the spectrophotometric resorcinol assay (Jensen 1962). Starch was extracted overnight from the ethanol-insoluble residue in $1 \mathrm{~N}$ $\mathrm{KOH}$ and determined spectrophotometrically using an anthrone assay standardised to sucrose (Jensen 1962).

Carbon and nutrient ( $\mathrm{N}$ and $\mathrm{P}$ ) concentrations were measured in independent triplicate samples ( $\mathrm{n}=6$ shoots) of dried adult (i.e. those with differentiated ligulae) and young (i.e. the rest) leaves and rhizomes obtained from shaded and control plots 20,50 and $90 \mathrm{~d}$ from the start of the shading experiments in 1995. $\mathrm{C}$ and $\mathrm{N}$ concentrations were determined using a Carlo-Erba CHN analyser and phosphorus by induced coupled plasma after acid digestion of the ground material (Mateo \& Sabaté 1993).

We used 1-way repeated-measures ANOVA (Green 1993, Lesica \& Steel 1997) to assess the statistical significance of the effect of shading (differences between treatments) on trends of the selected variables over the experimental period. Shading (3 levels: SS, MS and control) was the between-subject factor and time (i.e. sampling events) the repeated-measures (within-subject) factor. A paired sample $t$-test $(\mathrm{n}=2)$ was used to determine significant differences in mean values of photosynthetic parameters between May and August, obtained in $P$ - $I$ curves in the 1995 experiments. Before statistical analyses, all data were checked for normality and homoscedasticity and, when necessary, they were properly transformed (Zar 1984). When signifi- cant effects were detected by ANOVA, a posteriori pairwise comparisons of means were performed using the Student-Neuman-Keuls (SNK) comparison test. All differences were considered significant at $\mathrm{p}<0.05$.

\section{RESULTS}

\section{Light conditions}

The effects of shading treatments (MS and SS) on ambient light conditions over the experimental period at the Fraile Island meadow are summarised in Table 1 and illustrated in Fig. 3. Daily PPFD in controls (unshaded plots) increased from $5.5 \mathrm{~mol}$ quanta $\mathrm{m}^{-2} \mathrm{~d}^{-1}$ in May to 13-14 mol quanta $\mathrm{m}^{-2} \mathrm{~d}^{-1}$ in summer months, which is close to the maximum annual irradiance values in the study area. Daily averaged PPFD was reduced 37 to $41 \%$ (relative to control) in MS screens and 62 to $66 \%$ in SS screens, which indicates that there was little deviation from the initial shading values throughout the period. While control plots received $35.8 \%$ of the surface irradiance (corresponding to an average coefficient of light attenuation of $k=0.11 \mathrm{~m}^{-1}$ ), shaded plots received much less, 16.7 and $10.4 \% I_{\mathrm{s}}$ in MS and SS, respectively; for this depth $(10 \mathrm{~m})$, the latter values are the PPFD that would be expected if $k$ in water were 0.2 and $0.25 \mathrm{~m}^{-1}$, respectively.

\section{Shoot survival}

Shading caused significant shoot mortality; the decrease in shoot density in shaded plots was evident in both 1993 and 1995 experiments (Fig. 4). Differences in the shoot number between treatments were highly significant (Table 2), and the time course of this variable also differed between shaded and unshaded plants

Table 1. Posidonia oceanica. Effect of experimental shading treatments (MS and SS, moderate and severe shading, respectively) on ambient light conditions (i.e. control plots) at the top of the leaf canopy in the Fraile Island meadow. PPFD: photosynthetic photon flux density. $k$ was computed as $\left(\ln I_{\mathrm{S}}-\ln I_{\mathrm{z}}\right) / z$, with $I_{\mathrm{S}}$ and $I_{z}$ being the irradiance values at the surface and the canopy level (i.e. below the screens, where existing), respectively, and $z$ the depth (i.e. 8 to $10 \mathrm{~m}$ )

\begin{tabular}{|c|c|c|c|c|}
\hline Month & Light conditions & Control & MS & SS \\
\hline May & $\begin{array}{l}\left.\text { PFFD (mol quanta } \mathrm{m}^{-2} \mathrm{~d}^{-1}\right) \\
\text { light reduction }(\%)\end{array}$ & $\begin{array}{c}5.5 \pm 0.3 \\
0\end{array}$ & $\begin{aligned} 3.5 & \pm 0.1 \\
41 & \pm 1\end{aligned}$ & $\begin{array}{l}1.75 \pm 0.15 \\
66.9 \pm 0.5\end{array}$ \\
\hline Jun & $\begin{array}{l}\text { PFFD (mol quanta } \mathrm{m}^{-2} \mathrm{~d}^{-1} \text { ) } \\
\text { light reduction }(\%)\end{array}$ & $\begin{array}{c}14.3 \pm 0.35 \\
0\end{array}$ & $\begin{array}{r}9.2 \pm 0.5 \\
37.2 \pm 3.4\end{array}$ & $\begin{array}{r}5.4 \pm 0.5 \\
62.6 \pm 3.4\end{array}$ \\
\hline \multirow[t]{2}{*}{ Jul } & $\begin{array}{l}\left.\text { PFFD (mol quanta } \mathrm{m}^{-2} \mathrm{~d}^{-1}\right) \\
\text { light reduction }(\%)\end{array}$ & $\begin{array}{c}13.2 \pm 0.05 \\
0\end{array}$ & $\begin{array}{r}8.2 \pm 0.4 \\
37.3 \pm 3.6\end{array}$ & $\begin{array}{r}4.9 \pm 0.5 \\
62.6 \pm 3.6\end{array}$ \\
\hline & $\begin{array}{l}\% I_{\mathrm{s}} \\
k\left(\mathrm{~m}^{-1}\right)\end{array}$ & $\begin{array}{l}35.8 \pm 1.02 \\
0.11 \pm 0.004\end{array}$ & $\begin{aligned} 16.7 & \pm 1.1 \\
0.2 & \pm 0.004\end{aligned}$ & $\begin{array}{l}10.4 \pm 0.64 \\
0.25 \pm 0.009\end{array}$ \\
\hline
\end{tabular}




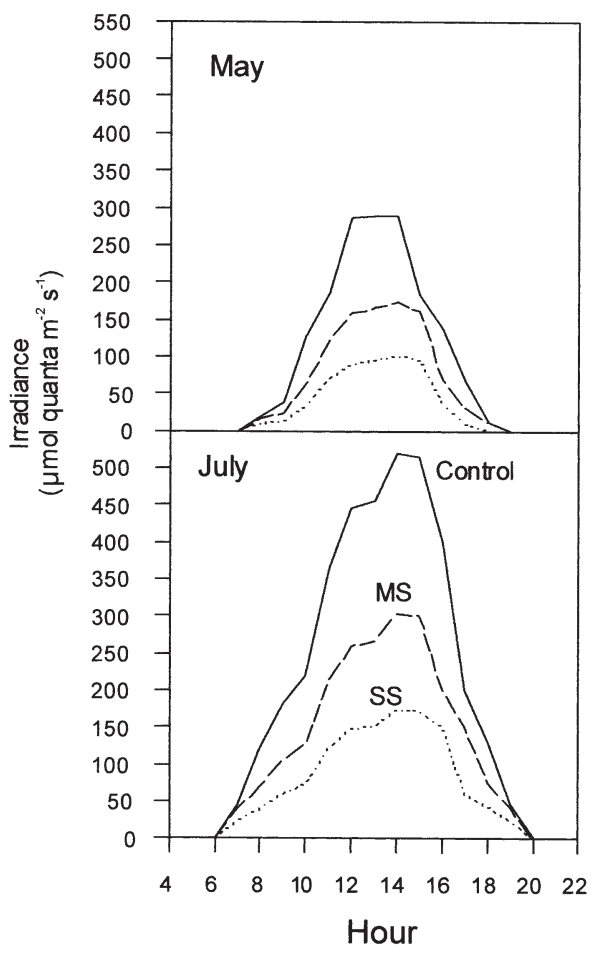

Fig. 3 Daily evolution of incident irradiance in control (solid line), MS screens (dashed line) and SS screens (dotted line) at the beginning (May) and the end (July) of the shading experimental period

(significant interaction term in Table 2). At the end of the shading period, surviving shoots in MS were 20 to $30 \%$ of initial values, and only $10 \%$ in SS, while shoot number in control plots did not change significantly. In the 1995 experiments, the number of shoots showed a very mild trend of further decline in shaded plots after screen removal, but this trend (reflected in the time $x$ treatment interaction term) only marginally differed from that of controls.

\section{Shoot characteristics}

Shoot size and leaf growth rate were consistently lower in shaded than in control plots (Fig. 5, Table 2). Decreases in these variables depended on the shading treatment, being higher in SS plots (66 to $71 \%$ relative to control means) than in MS ones (33 to $43 \%$ relative to control means) at the end of the shading period. Differences between shading and control treatments were consistent from the beginning of the shading period (from May to July) and persisted (MS plots) or increased (SS plots) until the end of the period (September). In October (post-shading period), differences between shaded and control plots remained in leaf growth rates but not in shoot size (Fig. 5, Table 2). However, shaded and control plots did not show significant differences in time-trends for either variable in the post shading period (shading $[\mathrm{S}] \times$ time $[\mathrm{T}]$ interaction term, Table 2).

In the 1993 experiment, the number of leaves per shoot followed the same trend as shoot size and shoot growth. However, in 1995 experiment the number of leaves per shoot decreased markedly in shaded plots at the end of the shading period (Fig. 5, see significant $\mathrm{S} \times \mathrm{T}$ interaction term in Table 2). These differences between shaded and unshaded plots did not disappear in the post-shading period.

The epiphyte load variable was the most strongly affected by shading, as shown by the high variability explained by the treatment (88 to $98 \%$, see Table 2). Epiphyte loads in shaded plots were substantially lower (by 60 to $80 \%$ ) than in control plots throughout the shading period. There were no significant differences in epiphyte load among shading treatments (MS and $\mathrm{SS}_{\text {; }} \mathrm{SNK}, \mathrm{p}>0.05$; Fig. 5). The time course of epiphyte load variations during the shading period was identical between shaded and control plots; in contrast, in the MS plots from the 1995 experiments, once the screens were removed, epiphyte load reattained the same values as those of control plots (Fig. 5, Table 2).

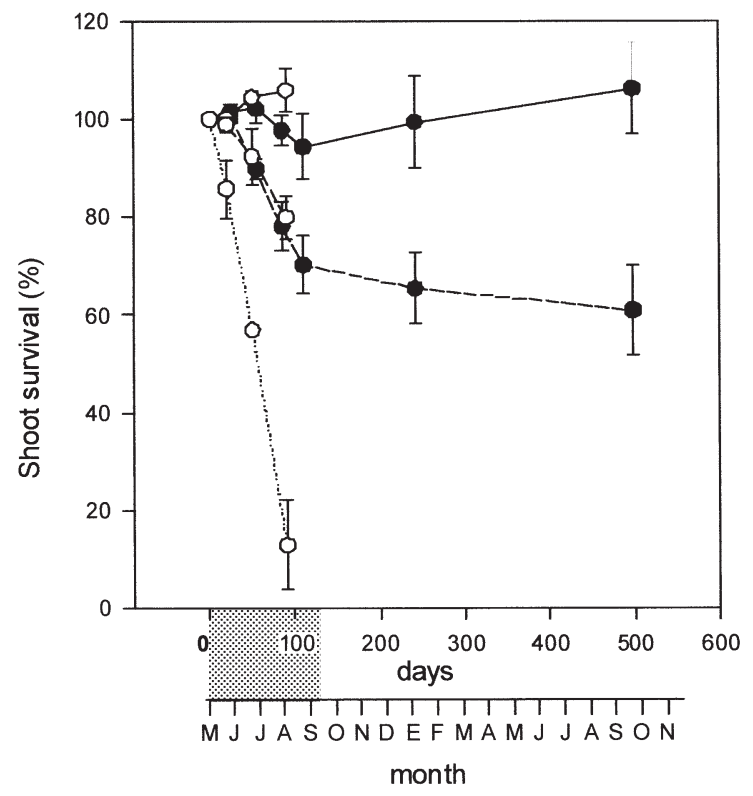

Fig. 4. Posidonia oceanica. Average shoot survival in $625 \mathrm{~cm}^{2}$ fixed quadrats in control plots (solid line), under MS screens (dashed line) and under SS screens (dotted line), measured over shading and post-shading periods in 1993 (white circles) and 1995 (black circles). Shaded area: duration of the shading period. Vertical bars: standard error (SE) 
Table 2. Summary of the 1-way repeated-measures ANOVA performed to assess the significance of shading and time effects on each of the selected plant variables in 1993 and 1995 experiments. \% var. = percentage of explained variance; ns = not significant; ${ }^{*} \mathrm{p}<0.05{ }_{i}^{* *} \mathrm{p}<0.01{ }^{* * *} \mathrm{p}<0.001$

\begin{tabular}{|c|c|c|c|c|c|c|c|c|c|c|}
\hline \multirow[t]{3}{*}{ Variable } & \multirow[t]{3}{*}{ Effect } & \multirow{2}{*}{\multicolumn{3}{|c|}{$\frac{}{1993}$ Shadin }} & & & & \multicolumn{3}{|c|}{ Post-shading period } \\
\hline & & & & & & \multicolumn{2}{|c|}{1995} & & & \\
\hline & & df & $\mathrm{p}$ & $\%$ var. & $\mathrm{df}$ & $\mathrm{p}$ & $\%$ var. & df & $\mathrm{p}$ & $\%$ var. \\
\hline \multirow{5}{*}{$\begin{array}{l}\text { Shoot density } \\
\left(\text { shoots } 625 \mathrm{~cm}^{-2} \text { ) }\right.\end{array}$} & Shading (S) & 2 & \multirow[t]{2}{*}{$* * *$} & 58.6 & 1 & \multirow[t]{2}{*}{$* *$} & 60.5 & 1 & \multirow[t]{2}{*}{$*$} & 88 \\
\hline & Error 1 & 6 & & 0.4 & 6 & & 9.8 & 6 & & 0.2 \\
\hline & Time $(\mathrm{T})$ & 3 & \multirow{3}{*}{${ }^{* * * *}$} & 24.1 & 4 & $* * *$ & 23.3 & 2 & \multirow{3}{*}{$\begin{array}{c}\mathrm{ns} \\
*\end{array}$} & 9.3 \\
\hline & $\mathrm{S} \times \mathrm{T}$ & 6 & & 16.4 & 4 & ${ }^{* *}$ & 9.8 & 2 & & 1.9 \\
\hline & Error 2 & 18 & & 0.5 & 28 & & 4.7 & 12 & & 0.3 \\
\hline \multirow{5}{*}{$\begin{array}{l}\text { Shoot size } \\
\left(\mathrm{g} \mathrm{dw} \text { shoot }^{-1}\right)\end{array}$} & $\mathrm{S}$ & 2 & \multirow[t]{2}{*}{$* * *$} & 49.2 & 1 & * & 34.5 & 1 & \multirow[t]{2}{*}{ *** } & 56.7 \\
\hline & Error 1 & 6 & & 1.7 & 4 & & 6.3 & 4 & & 0.6 \\
\hline & $\mathrm{T}$ & 2 & $* * *$ & 42.4 & 2 & $*$ & 50.8 & 2 & $* * *$ & 36 \\
\hline & $\mathrm{S} \times \mathrm{T}$ & 4 & \multirow[t]{2}{*}{$\mathrm{ns}$} & 4.8 & 2 & ns & 4.6 & 2 & \multirow[t]{2}{*}{ ns } & 5.2 \\
\hline & Error 2 & 12 & & 1.7 & 8 & & 3.6 & 8 & & 1.3 \\
\hline \multirow{5}{*}{$\begin{array}{l}\text { Leaf growth rate } \\
\left(\mathrm{mg} \mathrm{dw} \text { shoot }^{-1} \mathrm{~d}^{-1}\right)\end{array}$} & $\mathrm{S}$ & 2 & \multirow[t]{2}{*}{$* *$} & 38.2 & 1 & * & 34.6 & 1 & \multirow[t]{2}{*}{${ }^{*}$} & 62.8 \\
\hline & Error 1 & 6 & & 1.9 & 4 & & 4.8 & 4 & & 5.1 \\
\hline & $\mathrm{T}$ & 2 & $* * *$ & 56 & 2 & $* * *$ & 55.9 & 2 & $* * *$ & 28.8 \\
\hline & $\mathrm{S} \times \mathrm{T}$ & 4 & \multirow[t]{2}{*}{ ns } & 2.2 & 2 & ns & 2.3 & 2 & \multirow[t]{2}{*}{$\mathrm{ns}$} & 0.03 \\
\hline & Error 2 & 12 & & 1.4 & 8 & & 2.1 & 8 & & 3 \\
\hline \multirow{5}{*}{$\begin{array}{l}\text { Number of leaves } \\
\text { (leaves shoot }^{-1} \text { ) }\end{array}$} & $\mathrm{S}$ & 2 & \multirow[t]{2}{*}{$* * *$} & 47.8 & 1 & ns & 13.6 & 1 & \multirow[t]{2}{*}{$* * *$} & 32.7 \\
\hline & Error 1 & 6 & & 1.1 & 4 & & 3.8 & 4 & & 1.1 \\
\hline & $\mathrm{T}$ & 2 & $* * *$ & 48.1 & 2 & $* *$ & 33.3 & 2 & $* * *$ & 59 \\
\hline & $\mathrm{S} \times \mathrm{T}$ & 4 & ns & 1.8 & 2 & $* * *$ & 46.9 & 2 & ns & 4.3 \\
\hline & Error 2 & 12 & & 0.9 & 8 & & 2.1 & 8 & & 2.6 \\
\hline Epiphyte load & $\mathrm{S}$ & 2 & $* * *$ & 97.2 & 1 & $* * *$ & 88.9 & 1 & *** & 58.6 \\
\hline$\left(\mathrm{mg} \mathrm{dw} \mathrm{cm}^{-2}\right)$ & Error 1 & 6 & & 0.4 & 4 & & 2.2 & 4 & & 2.2 \\
\hline & $\mathrm{T}$ & 2 & $\mathrm{~ns}$ & 0.2 & 2 & ns & 4.7 & 2 & ns & 4.7 \\
\hline & $\mathrm{S} \times \mathrm{T}$ & 4 & $\mathrm{~ns}$ & 1.2 & 2 & ns & 2.8 & 2 & $* * *$ & 2.8 \\
\hline & Error 2 & 12 & & 0.7 & 8 & & 1.2 & 8 & & 1.2 \\
\hline Starch & $\mathrm{S}$ & & & & 1 & $* *$ & 75.5 & 1 & * & 74.8 \\
\hline$(\%)$ & Error 1 & & & & 4 & & 1.5 & 4 & & 5.1 \\
\hline & $\mathrm{T}$ & & & & 2 & ns & 5.9 & 2 & $* *$ & 15 \\
\hline & $\mathrm{S} \times \mathrm{T}$ & & & & 2 & ns & 11.9 & 2 & ns & 3.6 \\
\hline & Error 2 & & & & 8 & & 4.9 & 8 & & 1.1 \\
\hline Soluble sugars & $\mathrm{S}$ & & & & 1 & $*$ & 56.4 & & & \\
\hline$(\%)$ & Error 1 & & & & 3 & & 5 & & & \\
\hline & $\mathrm{T}$ & & & & 2 & ns & 14.9 & & & \\
\hline & $\mathrm{S} \times \mathrm{T}$ & & & & 2 & ns & 12.9 & & & \\
\hline & Error 2 & & & & 6 & & 10.6 & & & \\
\hline
\end{tabular}

\section{Photosynthetic activity}

Shading caused a decrease in $P_{\text {max }} I_{\text {sat }}$ and $I_{\mathrm{C},}$ and an increase in photosynthetic efficiency ( $\alpha$, initial slope). In the 1993 experiment, this response was greatest in the most shaded (SS) plots (Table 3 ). $P_{\max }, I_{\text {sat }}, I_{\mathrm{c}}$ and dark respiration $(R)$ changed through the experimental period in the 1995 experiments; in general terms they tended to increase from May (spring) to June and further increased in August (summer) in plants from unshaded plots, while they first increased (in June) and then decreased (in August) in plants from shaded plots (Fig. 6, Table 3). Conversely, photosynthetic efficiency $(\alpha)$ showed a marked decrease in unshaded plots throughout the experimental period, while in the shaded plots this parameter first decreased and then increased (Table 3). As a consequence of changes in $I_{\text {sat}}, H_{\text {sat }}$ in shading treatments (MS and SS) was ca $2 \mathrm{~h}$ higher than in control plots (ca $10 \mathrm{~h}$, Table 3). Daily C net gain of leaves calculated from $H_{\text {sat }}$ and $P_{\max }$ values decreased as the severity of the shading treatment increased (Table 3); in the 1995 experiment, differences in $P_{\max }, H_{\text {sat }}$ and the daily net carbon gains of leaves between shaded (MS) and control plots was also significant in August ( $t$-test, $\mathrm{p}<0.05$; Table 3).

\section{Rhizome carbohydrates}

Starch concentration in rhizomes was substantially lower in shaded than in control plots (Fig. 7, Table 2). Starch concentrations in control plots increased by 


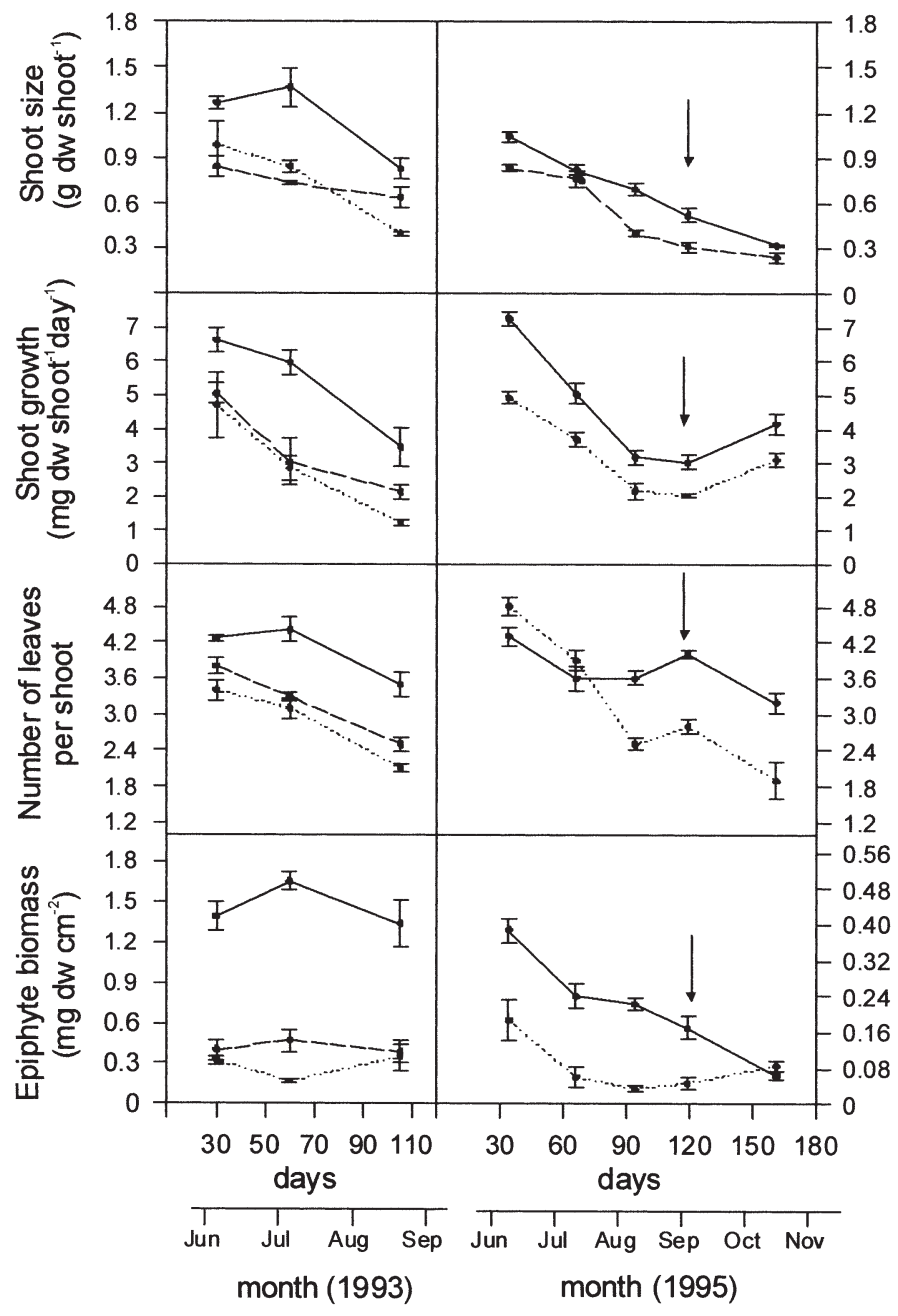

Fig. 5. Posidonia oceanica. Average shoot size, leaf growth rate, number of leaves per shoot and epiphyte load in control plots (solid line) and under MS (dashed line) and SS (dotted line) screens in 1993 (left-hand side) and 1995 (right-hand side) experiments. Vertical bars: standard error (SE). ( $($ ) Date when shading screens were removed in the 1995 experiments

$37.5 \%$ in June (i.e. $50 \mathrm{~d}$ of shading) in relation to shaded plots, and these differences persisted over time, even in the post-shading period (November). Soluble carbohydrates of shaded plots were significantly lower than those of control in May (i.e. $20 \mathrm{~d}$ of shading) but further converged to control values at the end of the shading period (August, $90 \mathrm{~d}$ of shading). No significant differences in the time course of either starch or soluble carbohydrate concentrations were observed between shaded and control plots (see interaction term $\mathrm{S} \times \mathrm{T}$ in Table 2).

\section{Tissue nutrient content}

Shading did not induce significant changes in carbon concentration in any of the plant parts considered, but caused a significant increase in the nitrogen concentration of adult and young leaves over the experimental period (Fig. 8). Differences in nitrogen content between shaded and control leaves were significant after $50 \mathrm{~d}$ of shading (SNK, p < 0.05 ) and increased above $2 \%$ at the end of the experimental period (Fig. 8). Shading caused moderate increases in the phosphorus concentration of adult leaf tissues but not in young leaves and significant differences among shaded and control plots were seen after $20 \mathrm{~d}$ of shading. Neither time nor the interaction time $\times$ treatments significantly affected nitrogen and phosphorus concentrations in leaf tissues.

\section{DISCUSSION}

\section{Response to shading}

Growth, biomass and survival of Posidonia oceanica shoots are significantly affected by changes in light availability due to shading. The first effect of shading was to reduce leaf growth rates and biomass of $P$. oceanica shoots, and it was detected $30 \mathrm{~d}$ after the beginning of shading. Other effects followed, and were evident after 2 to 3 mo (e.g. shoot mortality and defoliation). All these effects are common seagrass responses to in situ experimental shading (Backman \& Barilotti 1976, Dennison \& Alberte 1982, Bulthuis 1983, Gordon et al. 1994, Fitzpatrick \& Kirkman 1995, Lee \& Dunton 1997). The rapid reduction of $P$. oceanica leaf productivity and biomass is, in general terms, consistent with results obtained in other seagrass species when shading is imposed during the favourable growing season; however, it seems to be delayed in the unfavourable one, presumably because leaf growth is supported by internal carbon reserves (Bulthuis 1983, Neverauskas 1988, Lee \& Dunton 1997) or because leaf growth is minimum.

One reason to explain the reduction in plant growth and survival is the occurrence of imbalances in the carbon economy of the plant. Apart from the decrease in light reaching the seagrass canopy, the reduction in $P_{\max }$ can further decrease carbon assimilation. However, some compensatory mechanisms appear to counteract such imbalances. In effect, shading caused variations not only in $P_{\max }$ but also in other photosynthetic parameters $\left(I_{\text {sat }}, I_{\mathrm{c}}\right.$ and $\left.\alpha\right)$; such changes allowed an increase in photosynthetic efficiency $(\alpha)$, a lengthening of the daily period at which seagrass photosynthesised at saturating irradiance (i.e. $H_{\text {sat }}$ ) and the reduction of the dark respiration in summer (Table 3), thus indicating some degree of photoacclimation. 
Table 3. Photosynthetic parameters (mean \pm standard error) estimated from $P$ - $I$ curves obtained in June 1993 (after ca $60 \mathrm{~d}$ of shading) for MS and SS treatments and control plots, and in 1995 shading experiments (only control and MS treatment) after 20 (May), 50 (June) and 90 (August) d of shading. $P_{\text {max }}$ : net oxygen release at saturating irradiance $\left(\mathrm{mg} \mathrm{O}_{2} \mathrm{~g}^{-1} \mathrm{dw} \mathrm{h}^{-1}\right) ; R:$ dark respiration $\left(\mathrm{mg} \mathrm{O}_{2} \mathrm{~g}^{-1} \mathrm{dw} \mathrm{h}{ }^{-1}\right) ; I_{\text {sat }}$ : saturating irradiance ( $\mu \mathrm{mol}$ quanta $\left.\mathrm{m}^{-2} \mathrm{~s}^{-1}\right) ; I_{\mathrm{c}}$ : compensating irradiance $\left(\mu \mathrm{mol} \mathrm{quanta} \mathrm{m}^{-2} \mathrm{~s}^{-1}\right)$; $\alpha$ : photosynthetic efficiency; $H_{\text {sat }}$ : number of daily hours in which the plants received a PPFD that exceeded $I_{\text {sat }}$. $P_{\text {max }}: R$ ratio, together with average $H_{\text {sat }}$ and daily carbon net gains estimated using daily light curves and corresponding $P_{\text {max }}$ value (see 'Methods'), are also indicated in each case. ns = not significant; ${ }^{*} \mathrm{p}<0.05{ }_{i}^{* *} \mathrm{p}<0.01$

\begin{tabular}{|c|c|c|c|c|c|c|c|c|c|}
\hline \multirow[t]{2}{*}{ Parameter } & \multicolumn{9}{|c|}{1993 experiment (June, ca $60 \mathrm{~d}$ of shading) } \\
\hline & & \multicolumn{2}{|c|}{ Control } & \multicolumn{3}{|c|}{ MS } & \multicolumn{3}{|c|}{ SS } \\
\hline \multicolumn{2}{|l|}{$P_{\max }$} & \multicolumn{2}{|c|}{$6.89 \pm 1$} & \multicolumn{3}{|c|}{$4.54 \pm 0.53$} & \multicolumn{3}{|c|}{$2.95 \pm 0.15$} \\
\hline \multicolumn{2}{|l|}{$R$} & \multicolumn{2}{|c|}{$1.57 \pm 0.02$} & \multicolumn{3}{|c|}{$1.26 \pm 0.07$} & \multicolumn{2}{|c|}{$1.2 \pm 0.06$} & \\
\hline \multicolumn{2}{|l|}{$P_{\max }: R$} & \multicolumn{2}{|c|}{4.38} & \multicolumn{3}{|c|}{3.6} & \multicolumn{2}{|r|}{2.4} & \\
\hline & \multicolumn{2}{|c|}{$72.5 \pm 5.1$} & \multicolumn{3}{|c|}{$12.3 \pm 3.2$} & \multicolumn{2}{|c|}{$2.45 \pm 0.7$} & \\
\hline \multicolumn{2}{|l|}{$I_{\mathrm{C}}$} & \multicolumn{2}{|c|}{$12.8 \pm 1.7$} & \multicolumn{3}{|c|}{$1.97 \pm 1.83$} & \multicolumn{2}{|c|}{$0.68 \pm 0.42$} & \\
\hline & \multicolumn{2}{|c|}{$0.095 \pm 0.01$} & \multicolumn{3}{|c|}{$0.45 \pm 0.32$} & \multicolumn{2}{|c|}{$1.2 \pm 0.74$} & \\
\hline & & & & \multirow{3}{*}{\multicolumn{3}{|c|}{$\begin{array}{c}12 \pm 0.2 \\
17.1 \pm 0.33\end{array}$}} & & $6 \pm 0.22$ & \\
\hline \multirow{2}{*}{\multicolumn{2}{|c|}{$\begin{array}{l}\text { Daily C net gain } \\
\text { No photoacclimation: }^{\text {a }}\end{array}$}} & \multirow{2}{*}{\multicolumn{2}{|c|}{$21.9 \pm 0.48$}} & & & & 11.1 & $1 \pm 0.12$ & \\
\hline & & & & & & & & & \\
\hline$H_{\text {sat }}$ & & 10.6 & $=0.28$ & & $10.3 \pm 0.25$ & & & \pm 1.04 & \\
\hline Daily C net gain & & 22.02 & 0.58 & & $14.03 \pm 0.37$ & & & \pm 0.91 & \\
\hline Parameter & & 20 д (Ман) & & & 95 experimer & & & $90 d$ (Aurgust) & \\
\hline & Control & MS & $\mathrm{p}^{\mathrm{b}}$ & Control & MS & $\mathrm{p}^{\mathrm{b}}$ & Control & MS & $\mathrm{p}^{\mathrm{b}}$ \\
\hline$P_{\max }$ & $2.56 \pm 0.18$ & $3.08 \pm 0.15$ & ns & $10.9 \pm 0.37$ & $7.26 \pm 0.19$ & * & $12.5 \pm 0.33$ & $5.15 \pm 0.016$ & ${ }^{* *}$ \\
\hline$R$ & $1.16 \pm 0.08$ & $1.8 \pm 0.05$ & ns & $0.7 \pm 0.03$ & $0.97 \pm 0.06$ & ns & $1.22 \pm 0.05$ & $0.55 \pm 0.01$ & ${ }^{* *}$ \\
\hline$P_{\max }: R$ & 1.6 & 1.6 & & 15 & 7.4 & & 10.2 & 9.36 & \\
\hline$I_{\text {sat }}$ & $19 \pm 4.7$ & $22.5 \pm 3.7$ & & $228.7 \pm 20.2$ & $65.7 \pm 7.3$ & & $191.8 \pm 14$ & $20.9 \pm 0.31$ & \\
\hline$H_{\text {sat }}$ & $8.5 \pm 0.5$ & $8.7 \pm 0.25$ & & $9.5 \pm 0.28$ & $11.1 \pm 0.12$ & & $9.5 \pm 0.2$ & $12.7 \pm 0.25$ & \\
\hline$I_{\mathrm{C}}$ & $7.2 \pm 1.6$ & $8.12 \pm 1.18$ & & $14.2 \pm 2.79$ & $7.44 \pm 1.08$ & & $15 \pm 1$ & $1.5 \pm 0.07$ & \\
\hline$\alpha$ & $0.13 \pm 0.02$ & $0.13 \pm 0.01$ & & $0.1 \pm 0.049$ & $0.11 \pm 0.01$ & & $0.065 \pm 0.003$ & $0.24 \pm 0.003$ & \\
\hline$H_{\text {sat }}$ & $8.5 \pm 0.5$ & $8.7 \pm 0.25$ & $\mathrm{~ns}$ & $9.5 \pm 0.28$ & $11.1 \pm 0.12$ & $\mathrm{~ns}$ & $9.5 \pm 0.2$ & $12.7 \pm 0.25$ & ${ }^{*}$ \\
\hline Daily C net gain & $6.3 \pm 0.37$ & $7.85 \pm 0.25$ & ns & $31.05 \pm 0.9$ & $23.9 \pm 0.2$ & $\mathrm{~ns}$ & $36.5 \pm 0.95$ & $20.6 \pm 0.7$ & ${ }^{*}$ \\
\hline
\end{tabular}

This adaptation is a well-known plant response, and in seagrasses it has been described in relation to different causes of light reduction such as seasonality (Dennison 1987, Pérez \& Romero 1992, Alcoverro et al. 1998), depth (Dennison \& Alberte 1986) and light extinction within leaf canopies (Mazzella \& Alberte 1986, Carruthers \& Walker 1997). The results of those studies, as well as those presented here, show that this photoacclimation tends to balance the carbon budget under low light conditions. Indeed, as shown in Table 3, leaf carbon gains calculated using photosynthetic parameters estimated for each shading treatment were above the values expected if photoacclimation did not take place (i.e. if $H_{\text {sat }}$ of shaded plants did not differ from controls).

Reduction of epiphyte biomass also contributes to compensate the shift in carbon balance due to shading. In the growing season of the seagrass, epiphytic communities are dominated by photophilic algal species (Romero 1988), which are severely affected by light reduction (Fitzpatrick \& Kirkman 1995). A decrease in epiphyte biomass would increase light reaching the leaf surface; however, the quantitative importance of such an effect remains unknown, since epiphytes grow on old leaves, which are less important for the $\mathrm{C}$ budget than intermediate or young leaves (Alcoverro et al. 2001).

Some of the changes detected in the plant, such as defoliation or shoot mortality, should also affect its carbon budget (Zimmerman et al. 1989, Fourqurean \& Zieman 1991). On the one hand, defoliation causes a decrease in the photosynthetic biomass and hence decreases the positive side of the carbon budget. On the other hand, defoliation mainly affects the outermost, oldest leaves, which have the least contribution to carbon fixation (Alcoverro et al. 1998); moreover, defoliation decreases the leaf area index, as does shoot mortality, and then shelf-shading, which has been shown to exert an important influence on carbon gains in seagrasses (e.g. Pérez \& Romero 1992). Unfortu- 


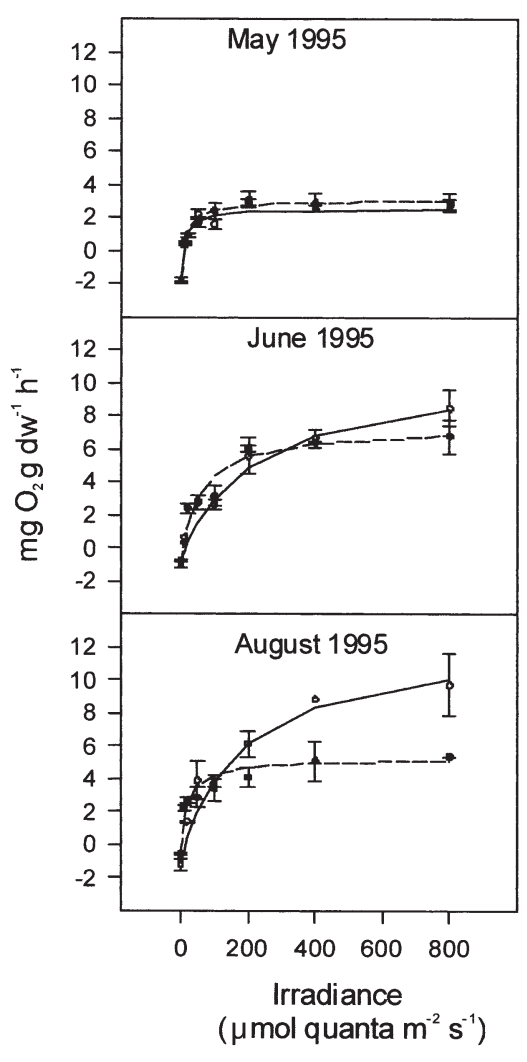

Fig. 6. Posidonia oceanica. P-I curves obtained in leaves from control plots (white circles, solid lines) and from MS treatment (black circles, dashed lines) in: May (after $20 \mathrm{~d}$ of shading), June (after $50 \mathrm{~d}$ of shading) and August (after $90 \mathrm{~d}$ of shading) in 1995. Vertical bars: standard error (SE)

nately, at the present stage of our knowledge, it is far from possible to quantitatively evaluate the impact of such changes on the carbon budget of the plant.

Another significant shading effect was the increase in the nitrogen concentrations of the youngest Posidonia oceanica leaves, which can be probably an indirect effect of carbon imbalance. As reported in terrestrial plants, before leaf decay, nitrogen is retranslocated to more productive seagrass tissues (Chabot \& Hicks 1982); since leaf abscission may be accelerated by shading, the sharp increase of nitrogen in young leaves of $P$. oceanica may be explained by this mechanism. However, as shown in other seagrass species, such as Zostera capricorni (Abal et al. 1994) and $Z$. marina (van Lent et al. 1995), leaf nutrient concentrations could increase in response to shading merely because they are not used for growth.

A final compensatory mechanism may be the reduction in the belowground biomass, as indicated by the frequent observation of a distinct necrosis of the distal parts of rhizomes in the shaded plots. This observation is not conclusive with regard to the shift in the aboveground:belowground ratio, but reduction in biomass of

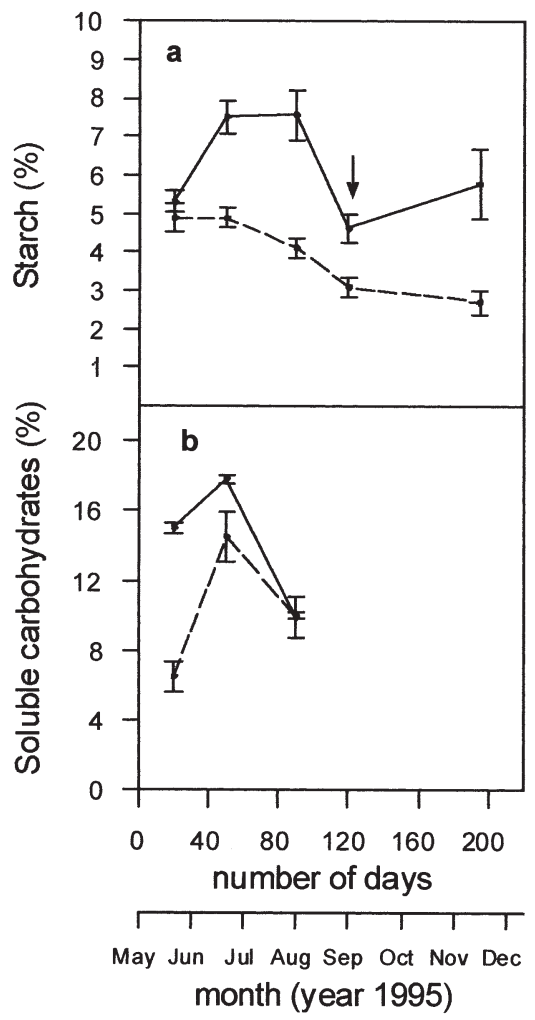

Fig. 7. Posidonia oceanica. Concentration (a) of starch and (b) soluble sugars in rhizomes from control plots (solid lines) and from MS shades (dashed lines) in 1995. ( $ـ$ Date when shading screens were removed. Vertical bars: standard error (SE)

roots and/or rhizomes would alleviate the heavy carbon demand by these organs, and hence contribute to plant survival.

The observed mortality can also be explained by reasons unrelated to carbon balance. In effect, reduced photosynthetic activity and leaf biomass due to shading can prevent adequate oxygenation of belowground parts, increasing the daily period of root/ rhizome anaerobiosis (Fourqurean \& Zieman 1991, Zimmerman et al. 1991, 1995, Lee \& Dunton 1997). Anoxia affects root metabolism (Smith et al. 1988), inhibits sucrose transport from source to sink tissues (Saglio 1985) and prevents the formation of the aerobic rhizosphere (Smith et al. 1984). Some authors suggest that in response to shading meadow collapse occurs when carbohydrate reserves are depleted by respiratory demands (Gordon et al. 1994, Lee \& Dunton 1997); however, anoxia of the belowground organs may be more crucial. The necrosis of tissues in the basal parts of rhizomes in shaded plots (see above) may be the result of an inadequate oxygenation of belowground parts. The ability to tolerate root/rhizome anaerobiosis has been studied only in a 


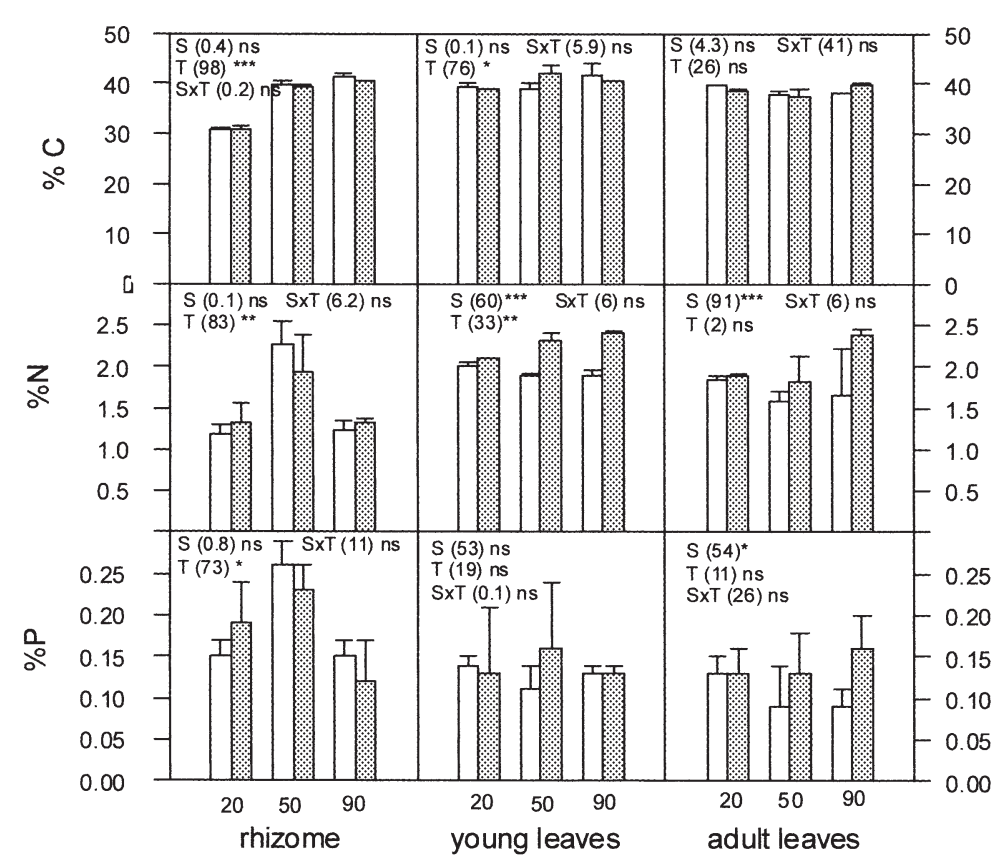

Fig. 8. Posidonia oceanica. Carbon and nutrient ( $\mathrm{N}$ and $\mathrm{P}$ ) concentrations in young leaves, adult leaves and rhizomes measured in the 1995 experiment in samples from control plots (white bars) and MS shades (shaded bars) after 20,50 and $90 \mathrm{~d}$ of shading. Partition of variance (\% of variance, number in parentheses) and significance of the main effects (S: shading, $\mathrm{T}$ : time, $\mathrm{S} \times \mathrm{T}$ : interaction term) as derived from ANOVA are indicated in each case. ns $=$ not significant $;{ }^{*} \mathrm{p}<0.05_{i}{ }^{* *} \mathrm{p}<0.01 ;{ }^{* * *} \mathrm{p}<0.001$. Vertical bars: standard error (SE)

few seagrass species (Penhale \& Wetzel 1983, Pregnall et al. 1984), and never, as far as we are aware, in Posidonia oceanica; yet it may be a key factor in understanding the interspecific differences between seagrasses in low light environments.

Our results show that the plant is able to survive under moderate shading (i.e. MS plots), although with a lower shoot density, but cannot persist under severe shading. Leaf carbon gains in SS plots are extremely low, and do not meet the minimum requirements for growth and respiratory demands. The rapid shoot mortality shown by Posidonia oceanica in SS plots indicates a high sensitivity to persistent light reduction. The time-response of shoot mortality $(4 \mathrm{mo})$ is the lowest reported for seagrasses (see, for example, P. australis [9 mo, Fitzpatrick \& Kirkman 1995] or Heterozostera tasmanica [14 mo, Bulthuis 1983]). This result is, in general terms, consistent with the hypothesis that larger seagrass species such as Posidonia or Thalassia, with massive belowground biomass, have higher light requirements and are, therefore, more sensitive to light reduction than smaller ones (e.g. H. tasmanica; Abal et al. 1994, Alcoverro et al. 1995).

Our results suggest that minimum light requirements for Posidonia oceanica are between 16.7 and
$10.4 \%$ of surface irradiance $\left(I_{\mathrm{s}}\right)$. In the absence of other limiting factors (substrate, sediment composition, etc.), light determines the maximum depth of seagrass distribution and light availability at this depth represents a whole-plant, yearly averaged compensating irradiance (i.e. $I_{\mathrm{c} i}$ Dennison 1987). Our short-term experiment does not necessarily fully reproduce the situation at the deep limit of the seagrass meadow, and key issues such as the light variability (both seasonal and interannual) and biomass partitioning between aboveground and belowground part should be taken into account. However, considering a mean light attenuation coefficient for the study area of 0.1 $\mathrm{m}^{-1}$ (Ruiz et al. 1993, pers. obs.) and the maximum depth attained by $P$. oceanica in nearby zones to be $25 \mathrm{~m}$, average light reaching this depth is, in effect, about $8 \%$ of surface light, which is almost equivalent to the light under SS shading, under which all shoots had died at the end of the experiment. P. oceanica deep limits in other localities along the Western Mediterranean coast appear at similar light values (10 to $15 \%$ of $I_{\mathrm{s}}$ : Drew 1978, Pirc 1984). This consistency suggests that our results has some predictive value that can be use for management purposes.

\section{Long-term effects}

It has been hypothesised that a drop in carbohydrate concentration in rhizomes during the most favourable season (e.g. summer for Posidonia oceanica) could be a reliable indicator of seagrass decline in the unfavourable growth season (Fitzpatrick \& Kirkman 1995, Lee \& Dunton 1997). Carbohydrate reserves in $P$. oceanica shoots in MS plots decreased up to $60 \%$ of those in control plots at the end of the experimental period, but little or no reduction in shoot densities was further observed in MS plots $1 \mathrm{yr}$ after shades had been removed, indicating the absence of cascading effects. During this time shoots from shaded plots showed vigorous external features, and we were unable to find any morphological difference between them and neighbouring unshaded shoots. This suggests that, after shading, surviving shoots had enough reserves to persist until the next growing season, or, alternatively, that the compensatory mechanisms previously described (e.g. mortality of belowground parts, with a high respiratory demand) were enough to permit the plant to survive the unfavourable season. How- 
ever, no signs of recovery in shoot densities were observed. The inability of $P$. oceanica to recover abundance after a mortality event seems to be a common feature of the Posidonia genus (Gordon et al. 1994, Fitzpatrick \& Kirkman 1995), but contrasts with other seagrass species such as Z. marina (Backman \& Barilotti 1978). This could be due to the fact that Posidonia spp. have the largest belowground biomass and lowest rhizome elongation rates among seagrass species (Patriquin 1973, Hillman et al. 1989, Pergent \& Pergent-Martini 1990, Alcoverro 1995, Duarte et al. 1997). In addition, in $P$. oceanica, seedling is a very rare process (Caye \& Meinesz 1984), and hence recolonization of disturbed areas is only possible through horizontal growth from nearby patches or through vegetative propagation from other meadows, which are very slow processes. Few or no signs of seagrass recolonization have been found in damaged Posidonia meadows affected by local human impact (bombs, mining) several decades before (Meinesz \& Lefevre 1984, Shepherd et al. 1989). Thus, these results provide experimental evidence that shading, even in the short term (i.e. $3 \mathrm{mo}$ ) causes long-term effects on $P$. oceanica abundance. Therefore, the control and knowledge of the effects of human disturbance (e.g. dredging, sediment load, waste discharge, etc.) on light availability for seagrasses, must be of primary concern for managers if $P$. oceanica meadows are to be preserved.

Acknowledgements. Financial support for this study was in part provided by a grant from the University-Enterprise Foundation of Murcia and by grant CICYT MAR98-0356. Special thanks to Dr A. Marín for providing space and facilities during the study. We thanks the director and staff of the yachting harbour of Aguilas, as well as CULMAREX SA, for logistical support. N and P analyses were done at the 'Serveis Científico-Tècnics de l'Universitat de Barcelona'. We thank Jose Miguel Gutiérrez and Ana Fernández for providing digitised maps of the study area.

\section{LITERATURE CITED}

Abal EG, Loneragan N, Bowen P, Perry CJ, Udy JW, Dennison WC (1994) Physiological and morphological responses of the seagrass Zostera capricorni Aschers. to light intensity. J Exp Mar Biol Ecol 178:113-129

Alcoverro T (1995) Production ecology of the Mediterranean seagrass Posidonia oceanica (L.) Delile. Tesis Doctoral, Departament d'Ecologia, Universitat de Barcelona

Alcoverro T, Duarte CM, Romero J (1995) Annual growth dynamics of Posidonia oceanica: contribution of largescale versus local factors to seasonality. Mar Ecol Prog Ser 120:203-210

Alcoverro T, Manzanera M, Romero J (1998) Seasonal and age scale-dependent variability of Posidonia oceanica (L.) Delile photosynthetic parameters. J Exp Mar Biol Ecol 230: $1-13$

Alcoverro T, Manzanera M, Romero J (2001) Annual metabolic carbon balance of the seagrass Posidonia oceanica: the importance of carbohydrate reserves. Mar Ecol Prog Ser 211:105-116

Backman TW, Barilotti DC (1976) Irradiance reduction: effects on standing crops of the eelgrass Zostera marina in a coastal lagoon. Mar Biol 34:33-40

Blanc JJ, Jeudy de Grissac A (1989) Réflexions géologiques sur la régression des herbiers à Posidonies (Départements du Var et des Bouches-du-Rhône). In: Boudouresque CF, Meinesz A, Fresi E, Gravez V (eds) Int Workshop on Posidonia oceanica Beds 2. GIS Posidonie, Marseille, p 273-285

Bourcier M (1989) Evolution, en cinq années, des herbiers à Posidonia oceanica et du macrobenthos circalitoral action conjuguée des activités humaines et des modifications climatiques. In: Boudouresque CF, Meinesz A, Fresi E, Gravez V (eds) Int Workshop on Posidonia oceanica Beds 2. GIS Posidonie, Marseille, p 287-292

Bulthuis DA (1983) Effects of in situ light reduction on density and growth of the seagrass Heterozostera tasmanica (Martens ex Aschers) den Hartog in Western Port, Victoria, Australia. J Exp Mar Biol Ecol 67:91-103

Carruthers TJB, Walker DI (1997) Light climate and energy flow in the seagrass canopy of Amphibolis griffithii (J. M. Black) den Hartog. Oecologia 109:335-341

Caye G, Meinesz A (1984) Observations sur la floraison et la fructification de Posidonia oceanica dans la Baie de Villefranche et en Corse du sud. In: Boudouresque CF, Jeudy de Grissac A, Olivier J (eds) Int Workshop on Posidonia oceanica Beds 1. GIS Posidonie, Marseille, p 193-201

Chabot BF, Hicks DJ (1982) The ecology of leaf spans. Annu Rev Ecol Syst 13:229-259

Czerny AB, Dunton KH (1995) The effects of in situ light reduction on the growth of two subtropical seagrasses, Thalassia testudinum and Halodule wrightii. Estuaries 18(2):418-427

Dawes CJ, Tomasko DA (1988) Depth distribution of Thalassia testudinum in two meadows on the west coast of Florida: a difference in effect of light availability. PSZN I: Mar Ecol 9(2):123-130

Delgado O, Grau A, Pou S, Riera F, Massuti C, Zabala M, Ballesteros E (1997) Seagrass regression caused by fish cultures in Fornells Bay (Menorca, Western Mediterranean). Oceanol Acta 20:557-563

Delgado O, Ruiz JM, Pérez M, Romero J, Ballesteros E (1999) Effects of fish farming on seagrass (Posidonia oceanica) in a Mediterranean bay: seagrass decline after organic loading cessation. Oceanol Acta 22(1):109-117

Dennison WC (1987) Effects of light on seagrass photosynthesis, growth and depth distribution. Aquat Bot 27:15-26

Dennison WC, Alberte RS (1982) Photosynthetic responses of Zostera marina L. (Eelgrass) to in situ manipulations of light intensity. Oecologia 55:137-144

Dennison WC, Alberte RS (1985) Role of daily light period in the depth distribution of Zostera marina (eelgrass). Mar Ecol Prog Ser 25:51-61

Dennison WC, Alberte RS (1986) Photoadaptation and growth of Zostera marina L. (eelgrass) transplants along a depth gradient. J Exp Mar Biol Ecol 98:265-282

Drew EA (1978) Factors affecting photosynthesis and seasonal variation in the seagrasses Cymodocea nodosa (ucria), and Posidonia oceanica (L.) Delile in the Mediterranean. J Exp Mar Biol Ecol 31:173-194

Drew EA (1983) Light. In: Earrll R, Erwin DG (eds) Sublittoral ecology. The ecology of the shallow sublittoral benthos. Clarendon Press, Oxford, p 10-57

Duarte CM (1991) Seagrass depth limit. Aquat Bot 40: 363-377 
Duarte CM, Terrados J, Agawin NSR, Fortes MD, Bach S, Kenworthy WJ (1997) Response of a mixed Philippine seagrass meadow to experimental burial. Mar Ecol Prog Ser $147: 285-294$

Fitzpatrick J, Kirkman H (1995) Effects of prolonged shading stress on growth and survival of seagrass Posidonia australis in Jervis Bay, New South Wales, Australia. Mar Ecol Prog Ser 127:279-289

Fourqurean JW, Zieman JC (1991) Photosynthesis, respiration and whole plant carbon budget of the seagrass Thalassia testudinum. Mar Ecol Prog Ser 69:161-170

Giesen WBJT, van Katwijk MM, den Hartog C (1990) Eelgrass condition and turbidity in the Dutch Wadden Sea. Aquat Bot 37:71-85

Gordon DM, Grey KA, Chase SC, Simpson CJ (1994) Changes to the structure and productivity of a Posidonia sinuosa meadow during and after imposed shading. Aquat Bot 47:265-275

Green RH (1993) Application of repeated measures designs in environmental impact and monitoring studies. Aust J Ecol 18:81-98

Herzka SZ, Dunton KH (1997) Seasonal photosynthetic patterns of the seagrass Thalassia testudinum in the western Gulf of Mexico. Mar Ecol Prog Ser 152:3-117

Hillman K, Walker DI, Larkum AWD, McComb AJ (1989) Productivity and nutrient limitation. In: Larkum AWD, McComb AJ, Shepherd SA (eds) Biology of seagrasses. A treatise on the biology of seagrasses with special reference to the Australian Region. Elsevier, Amsterdam, p 635-685

Jensen WA (1962) Botanical histochemistry. WH Freeman and Company, San Francisco

Kirchman DL, Mazzella L, Alberte RS, Mitchell R (1984) Bacterial epiphyte on Zostera marina. Mar Ecol Prog Ser 15: 207-211

Larkum AWD, West RJ (1983) Stability, depletion and restoration of seagrass beds. Proc Linn Soc NSW 106(3):201-211

Lee KS, Dunton KH (1997) Effects of in situ light reduction on the maintenance, growth and partitioning of carbon resources in Thalassia testudinum Banks ex Konig. J Exp Mar Biol Ecol 210:53-73

Lesica P, Steele B (1997) Use of permanent plots in monitoring plant populations. Nat Areas J 17(4):331-340

Lüning K (1990) Seaweeds. Their environment, biogeography and ecophysiology. John Wiley, New York

Manzanera M, Pérez M, Romero J (1998) Seagrass mortality due to oversedimentation: an experimental approach. J Coastal Conserv 4:67-70

Marbà N, Duarte CM (1997) Interannual changes in seagrass (Posidonia oceanica) growth and environmental change in the Spanish Mediterranean littoral zone. Limnol Oceanogr 42:800-810

Masini RJ, Cary JL, Simpson CJ, McComb AJ (1995) Effects of light and temperature on the photosynthesis of temperate meadow-forming seagrasses in Western Australia. Aquat Bot 49:239-254

Mateo MA, Sabaté S (1993) Wet digestion of vegetable tissue using a domestic microwave oven. Anal Chem 279: 273-279

Mazella L, Alberte RS (1986) Light adaptation and the role of autotrophic epiphytes in primary production of the temperate seagrass, Zostera marina (L.). J Exp Mar Biol Ecol 100:166-180

McRoy CP, McMillan C (1977) Production ecology and physiology of seagrasses. In: McRoy CP, Helfferich C (eds) Seagrass ecosystems: a scientific perspective. Marcel Dekker Inc, New York, p 53-87
Meinesz A, Lefevre JR (1984) Regénération d'un herbier de Posidonia oceanica quarante années après sa destruction par une bombe dans la rade de Villefranche (Alpes-Maritimes- France). In: Boudouresque CF, Meinesz A, Fresi E, Gravez V (eds) Int Workshop on Posidonia oceanica Beds 1. GIS POSIDONIE, Marseille, p 39-44

Meinesz A, Astier JM, Bodoy A, Cristiani G, Lefèvre JR (1982) Impact de l'aménagement du domaine maritime sur l'étage infralittoral des Bouches-du Rhône (FranceMéditerranée occidentale). Vie Milieu 32(2):115-124

Moore KA, Wetze RL, Orth RJ (1997) Seasonal pulses of turbidity and their relations to eelgrass (Zostera marina L.) survival in an estuary. J Exp Mar Biol Ecol 215:115-134

Neverauskas VP (1987) Monitoring seagrass beds around a sewage sludge outfall in South Australia. Mar Pollut Bull 18(4):158-164

Neverauskas VP (1988) Response of a Posidonia community to prolonged reduction in light. Aquat Bot 31:361-366

Patriquin D (1973) Estimation of growth rate, production and age of the marine angiosperm Thalassia testudinum konig. Bellairs Research Institute of Mcgill University, Barbados, p 111-123

Penhale PA, Wetzel RG (1983) Structural and functional adaptations of eelgrass (Zostera marina L.) to the anaerobic sediment environment. Can J Bot 61:1421-1428

Pérès JM (1984) La régression des herbiers à Posidonia oceanica. In: Boudouresque CF, Jeudy de Grissac A, Olivier J (eds) Int Workshop Posidonia oceanica Beds 1. GIS Posidonie, Marseille, p 445-454

Pérez M, Romero J (1992) Photosynthetic response to light and temperature of seagrass Cymodocea nodosa and the prediction of its seasonality. Aquat Bot 43:51-62

Pergent G, Pergent-Martini C (1990) Some applications of lepidochronical analysis in the seagrass Posidonia oceanica. Bot Mar 33:229-310

Pergent-Martini C, Pergent G (1995) Impact of a sewage treatment plant on the Posidonia oceanica meadow: assessment criteria. In: Özhan E (ed) Proc 2nd Int Conf on the Mediterranean coastal environment, MEDCOAST'95, Tarragona. MEDCOAST Secretariat, Middle East Technical University, Ankara, p 1389-1399

Pirc H (1984) Deep adaptation in Posidonia oceanica (L.) Delile. In: Boudouresque CF, Jeudy De Grissac A, Olivier J (eds) Int Workshop on Posidonia oceanica Beds 1. GIS Posidonie, Marseille, p 227-234

Pirc H (1986) Seasonal aspects of photosynthesis in Posidonia oceanica: influence of depth, temperature and light intensity. Aquat Bot 26:203-212

Pregnall AM, Smith RD, Alberte RS (1984) Metabolic adaptation of Zostera marina (eelgrass) to diurnal periods of root anoxia. Mar Biol 75:141-147

Pulich WM, White WA (1991) Decline of sumerged vegetation in the Galveston Bay system: chronology and relationships to physical processes. J Coast Res 7(4):1125-1138

Romero J (1988) Epífitos de las hojas de Posidonia oceanica: variaciones estacionales y batimétricas de biomasa en la pradera de las Islas Medes (Girona). Oecol Acuát 9:19-25

Romero J (1989) Primary production of Posidonia oceanica beds in the Medas Islands (Girona, NE Spain). In: Boudouresqsue CF, Meinesz A, Fresi E, Gravez V (eds) Int Workshop on Posidonia oceanica beds 2. GIS Posidonie, Marseille, p 85-91

Ruiz JM, Marín A, Calvo JF, Ramírez-Díaz L (1993) Interactions between floodway and coastal constructions in Aguilas Bay (Southeastern Spain). Ocean Coast Manage 19:241-262

Saglio PH (1985) Effect of path or sink anoxia on sugar trans- 
location in roots of maize seedlings. Plant Physiol 77: $285-290$

Sánchez-Lizaso JL, Guillén JE, Ramos A (1990) The regression of Posidonia oceanica meadows in El Campello (Spain). Rapp Comm Int Mer Médit 32(1) B-1/10:7

Shepherd SA, McComb AJ, Bulthuis DA, Neverauskas V, Steffensen DA, West R (1989) Decline of seagrasses. In: Larkum AW, McComb AJ, Shepherd SA (eds) Biology of seagrasses (A treatise on the biology of seagrasses with special reference to the australian region). Elsevier, Amsterdam, p 346-390

Silverstein K, Chiffings AW, McComb AJ (1986) The loss of seagrass in Cockburn Sound, Western Australia. III. The effect of epiphytes on productivity of Posidonia australis Hook F. Aquat Bot 24:355-371

Smith RD, Dennison WC, Alberte RS (1984) Role of seagrass photosynthesis in root anaerobic processes. Plant Physiol 74:1055-1058

Smith RD, Pregnall AM, Alberte RS (1988) Effets of anaerobiosis on root metabolism of Zostera marina (eelgrass): implications for survival in reducing sediments. Mar Biol 98:131-141

Terrados J, Ros JD (1995) Temperature effects on photosynthesis and depth distribution of seagrass Cymodocea nodosa (Ucria) Ascherson in a Mediterranean Coastal Lagoon: Mar Menor (SE Spain). PSZN I: Mar Ecol 16(2): $133-144$

Editorial responsibility: Otto Kinne (Editor), Oldendorf/Luhe, Germany van Lent F, Verschuure JM, van Veghel MLJ (1995) Comparative study on populations of Zostera marina L. (eelgrass): in situ nitrogen enrichment and light manipulation. J Exp Mar Biol Ecol 185:55-76

Walker DI, McComb AJ (1992) Seagrass degradation in Australian Coastal Waters. Mar Pollut Bull 25(5-8):191-195

West RJ (1990) Depth-related structural and morphological variations in an Australian Posidonia seagrass bed. Aquat Bot 36:153-166

Westlake DF (1963) Comparisons of plant productivity. Biol Rev 38:385-425

Zar HZ (1984) Biostatistical analysis. Prentice Hall, Englewood Cliffs, NJ

Zieman JC (1974) Methods for the study of the growth and production of turtle grass, Thalassia testudinum König. Aquaculture 4:139-143

Zimmerman RC, Smith RD, Alberte RS (1989) Thermal acclimation and whole-plant carbon balance in Zostera marina L. (eelgrass). J Exp Mar Biol Ecol 130:93-109

Zimmerman RC, Reguzzoni JL, Wyllie-Echeverria S, Josselyn M, Alberte RS (1991) Assesment of environmental suitability for growth of Zostera marina L. (eelgrass) in San Francisco Bay. Aquat Bot 39:353-366

Zimmerman RC, Reguzzoni RL, Alberte RS (1995) Eelgrass (Zostera marina L.) transplants in San Francisco Bay: role of light availability on metabolism, growth and survival. Aquat Bot 51:67-86

Submitted: June 30, 2000; Accepted: December 8, 2000 Proofs received from author(s): April 30, 2001 